\title{
Judging Music Libraries
}

\begin{abstract}
A survey of academic music librarians and members of the American Musicological Society provided a list of the top-ranked music libraries at academic institutions offering graduate degrees in music. A comparison between this study and earlier surveys rating graduate programs and professional schools demonstrates a strong relationship between the reputations of graduate programs in music departments and schools and the reputations of academic music libraries supporting such programs.
\end{abstract}

T 1 HE ASSESSMENT OF music libraries at institutions of higher education occurs at a time of uncertainty. It is an era of tight budgets, a time when most educational institutions have initiated extensive reviews of their programs. These reviews consider such elements as scope, mission, goals, objectives, needs, costs, and quality. They are undertaken in response to requests from inside and outside the institutions, many times initiated by state and national agencies.

Part of any such review involves evaluating the quality of the resources available to students and faculty. Several items recently identified as closely related to the educational quality of graduate programs include library resources, internal and external financial support, laboratory equipment, and computer facilities. ${ }^{1}$ With the exception of many locally sponsored studies and evaluations of music library resources and services, no national attempt has yet been made to assess the music libraries at academic institutions.

\section{THE SURVEY}

As a first step in a more extensive research project to develop guidelines for music library collections and services at institutions of higher education, the author

William M. McClellan is music librarian and professor of library administration, University of Illinois at Urbana-Champaign. The research for this study was supported by a fellowship from the Council on Library Resources. has identified what may be considered the top music libraries at academic institutions offering graduate programs in music. This was done by soliciting opinions of faculty, administrators, graduate students (members of the American Musicological Society), and music librarians employed at academic institutions. A brief two-part questionnaire was mailed to 325 individuals selected from a membership list of the American Musicological Society (AMS) and a directory of music librarians. ${ }^{2}$

One hundred names (3.2 percent of the total AMS membership) were selected from the list of 3,100 individual AMS members. Selection was limited to approximately 6.6 names per page and to those names that listed an academic address. Since the study was confined to the opinions of academic music faculty, administrators, and graduate students, this proved to be a successful way to exclude AMS members not affiliated with academic institutions. A larger sample of 225 names (38 percent of the total directory) was selected from the 593 names in the directory of music librarians. An average of 7.5 names of librarians affiliated with academic institutions were selected from each page in the directory.

Questionnaires required answers to the following two questions: "What, in your opinion, are the top five music libraries at academic institutions offering undergraduate degrees in music?" and "What, in your opinion, are the top five music libraries at academic institutions offering graduate pro- 
grams in music?" The latter question involved institutions offering master's and/or doctoral degrees in music. This survey used the same basic method employed by Peter Blau and Rebecca Margulies in their research on American professional schools. ${ }^{3}$

The respondents were asked not to rank the music libraries and to exclude the institution with which they were currently affiliated. The exclusion of libraries at institutions where the respondents were currently affiliated meant that some of the topranked libraries may have lost a few percentage points in the final tally. Self-ratings, or nominations of schools by their own deans, were also excluded in the BlauMargulies study, which polled deans of seventy accredited and university-affiliated music schools. In an earlier study conducted by Roose and Anderson, the 126 raters could include their own instititions in the questionnaire. ${ }^{4}$ However, the RooseAnderson study also analyzed the participants by type (chairperson, senior scholar, junior scholar), by degree of rater association with the rated institution (employed by, earned Ph.D. from), and by geographic region of the rater's institution of employment.

To maintain a certain anonymity, the respondents were also asked not to sign their names; but they were asked to indicate their current occupation or position. A selfaddressed, stamped envelope was enclosed for the convenience of the respondent. (The types of persons responding to the questionnaire included assistant, associate, and full professors; some graduate students; administrators [deans, chairpersons, department heads]; and music librarians [catalogers, fine arts librarians, department librarians, etc. ].)

No follow-ups were made to the initial mailing, which took place during March. 1976. Five of the original 325 requests were not delivered, and 156 (or 49 percent) usable responses were returned. (Eleven people returned the requests with various explanations of why they could not answer either of the questions.) There were 52 usable responses from the mailing to the 100 AMS members, and 104 usable responses from the 225 academic music librarians to whom requests were mailed.
The responses to question number 1 were varied and included listings for both undergraduate and graduate institutions. Replies were received from 131 respondents (approximately 41 percent) for this question. Although there are institutions of higher education that grant both undergraduate and graduate degrees in music, none is an exclusively graduate-degree granting institution. A small number of colleges, mainly liberal arts colleges, grant only undergraduate degrees in music, and the responses to this question indicated that there was not a clear consensus of top music libraries at undergraduate institutions.

In seventy-seven of the responses to the first question, only graduate-level institutions were listed as having the top music libraries to support undergraduate degrees in music, while thirty-seven respondents listed a mixture of both undergraduate and graduate-level institutions. Only seventeen respondents listed mainly undergraduate institutions. Because of this ambiguity in the first question, which failed to indicate that only academic institutions offering primarily undergraduate degrees in music were to be included in the response, the results of the survey did not prove valid for that question.

\section{Rankings of Graduate Programs}

Table 1 shows the rankings of the music libraries at the institutions offering graduate programs in music, according to the judgment of academic music librarians and AMS members. These rankings are based on the total number of times a given school was mentioned by the respondents. Next to each institution in the table is the percentage of respondents who rated the music library at the institution as one of the top five. The fifteen institutions listed in column one represent 6.4 percent or more of the total respondents' choices. It was felt that listing institutions named by a total of less than 10 percent of the responses would not be meaningful, and so more are listed to show the breadth of responses.

Caution should be used when interpreting the rankings based on small differences in the percentages; percentage differences are better indications of differences in reputations than are the rankings. Based on these percentages, the fifteen institutions 
TABLE 1

RANKING OF MUSIC LIBRARIES BY MUSIC LIBRARIANS AND AMS MEMBERS *

\begin{tabular}{|c|c|c|c|c|c|}
\hline Institution & $\begin{array}{c}\text { Percentage of } \\
\text { Music Librarians } \\
\text { and } \\
\text { AMS Members }\end{array}$ & Institution & $\begin{array}{c}\text { Percentage of } \\
\text { Music } \\
\text { Librarians }\end{array}$ & Institution & $\begin{array}{c}\text { Percentage of } \\
\text { AMS } \\
\text { Members }\end{array}$ \\
\hline $\begin{array}{l}\text { 1. Berkeley } \\
\text { 2. Eastman } \\
\text { 3. Harvard } \\
\text { 4. Yale } \\
\text { 5. Illinois } \\
\text { 6. Indiana } \\
\text { 7. Michigan } \\
\text { 8. Princeton } \\
\text { 9. Chicago } \\
\text { 9. North Carolina } \\
\text { 11. UCLA } \\
\text { 12. Columbia } \\
\text { 13. Stanford } \\
\text { 13. Northwestern } \\
\text { 15. Cornell }\end{array}$ & $\begin{array}{l}74.3 \\
70.5 \\
66.6 \\
64.1 \\
38.4 \\
32.6 \\
23 \\
20.5 \\
15.3 \\
15.3 \\
10.8 \\
9.6 \\
7.6 \\
7.6 \\
6.4\end{array}$ & $\begin{array}{l}\text { 1. Eastman } \\
\text { 2. Berkeley } \\
\text { 3. Yale } \\
\text { 4. Harvard } \\
\text { 5. Illinois } \\
\text { 6. Indiana } \\
\text { 7. Michigan } \\
\text { 8. North Carolina } \\
\text { 9. Chicago } \\
\text { 10. Princeton } \\
\text { 10. UCLA } \\
\text { 12. Columbia } \\
\text { 12. Northwestern } \\
\text { 14. North Texas } \\
\text { 15. Iowa(Iowa City) } \\
\text { 15. Stanford } \\
\text { 15. USC } \\
\text { 18. Cornell } \\
\text { 19. Washington } \\
\text { (St. Louis) }\end{array}$ & $\begin{array}{l}75 \\
74 \\
61.5 \\
60.5 \\
40.3 \\
35.5 \\
24 \\
19.2 \\
13.4 \\
11.5 \\
11.5 \\
8.6 \\
8.6 \\
6.7 \\
5.7 \\
5.7 \\
5.7 \\
4.8 \\
4.8\end{array}$ & $\begin{array}{l}\text { 1. Harvard } \\
\text { 2. Berkeley } \\
\text { 3. Yale } \\
\text { 4. Eastman } \\
\text { 5. Princeton } \\
\text { 6. Illinois } \\
\text { 7. Indiana } \\
\text { 8. Michigan } \\
\text { 9. Chicago } \\
\text { 10. Columbia } \\
\text { 10. Stanford } \\
\text { 12. Cornell } \\
\text { 12. UCLA } \\
\text { 14. North Carolina } \\
\text { 14. Pennsylvania }\end{array}$ & $\begin{array}{l}80.7 \\
75 \\
69.2 \\
61.5 \\
38.4 \\
34.6 \\
26.9 \\
21.1 \\
19.2 \\
11.5 \\
11.5 \\
9.6 \\
9.6 \\
7.6 \\
7.6\end{array}$ \\
\hline
\end{tabular}

"See appendix for full names of institutions listed.

form five basic groups. Berkeley, Eastman, Harvard, and Yale constitute the first group at the top of the scale, with Illinois and Indiana paired together at least twenty-six or more points below Yale from the top group. The third group, consisting of Michigan, Princeton, Chicago, and North Carolina, is separated from the fourth group, UCLA and Columbia, by only five points, while the fifth group, Stanford, Northwestern, and Cornell, is only two to three points below Columbia.

The relationship between the reputation rankings by academic music librarians and those by the AMS members can be found in the second and third sections of table 1 . Only two institutions show a marked difference of four or more positions in comparing the rankings by academic music librarians with the rankings by the AMS members. Thus North Carolina ranked eighth on the music librarians' list and fourteenth on the AMS members' list, and Princeton ranked tenth on the music librarians' list and fifth on the AMS members' list.

\section{COMPARISON STUDIES}

For comparison purposes table 2 has been prepared to show the findings for music from two earlier surveys: the BlauMargulies study, which ranked professional schools in various fields according to the collective judgments of the dean in each of the fields of study; and the Roose-Anderson survey, which ranked departments in thirty-six disciplines according to their reputations among scholars in the field.

\section{Blau-Margulies Study}

In the Blau-Margulies study the deans of seventy accredited and university-affiliated music schools were asked to name the top five professional music schools. The results of this survey are found in column one of table 2. Only four of the eight institutions in the Blau-Margulies study appear on the list of institutions in the first column of table 1. In this case there is little relation between reputable schools with applied music or conservatory-oriented programs and music libraries at graduate institutions. The Curtis Institute of Music, Juilliard School, and Oberlin College have strong reputations in the world of music making, but not in graduate education. The University of Southern California, rated seventh in the BlauMargulies study, is not ranked in the AMS list and is in fifteenth position on the academic music librarians' list in the second part of table 1 .

\section{Roose-Anderson Study}

A stronger relation appears between the 
reputations of music libraries and the ratings of graduate music programs, as indicated by answers to two of the questions asked by the Roose-Anderson study. The Roose-Anderson ranking of graduate music programs was based on responses from 126 raters, consisting of music department chairpersons, full professors, associate and assistant professors, and a mix of junior and senior scholars within the various academic ranks.

Respondents were asked to rate the quality of the graduate faculty and the effectiveness of the doctoral program and to give an estimate of recent change in the quality of graduate education. The ratings indicated by respondents resulted in the rankings of institutions shown in columns two and three of table 2. Fourteen of the fifteen institutions with ranked music libraries in column one of table 1 are included in the rankings determined by answers to the two questions of the Roose-Anderson study.

Two exceptions are Indiana and Northwestern. Indiana and Northwestern are not included on the list of institutions with rated doctoral programs (see column three, table 2), and Northwestern is also excluded from the ranked list of institutions with quality of graduate faculty (see column two, table 2). It should be mentioned, however, that Indiana and Northwestern were listed in the alphabetical group of institutions not ranked according to these questions in the Roose-Anderson study. In other words, those institutions having a total score below a certain number were not included in the rankings. ${ }^{5}$

Seven of the institutions in column one of table 1 show a difference of four or more positions in a comparison of these rankings with the two Roose-Anderson rankings. Placed ninth among music libraries (column one, table 1), Chicago appears fifth in quality of graduate faculty, while Eastman, second among music libraries, is ranked fourteenth in quality of graduate faculty and twelfth in effectiveness of doctoral program. Indiana ranked sixth among music libraries and thirteenth in quality of graduate faculty. Although North Carolina is ranked ninthalong with Chicago-in column one of table 1, it appears fourteenth in quality of graduate faculty, while Princeton ranked eighth among music libraries and second for both quality of the graduate faculty and the effectiveness of the doctoral program. Ranked thirteenth in the list of music libraries (column one, table 1), Stanford appears eighth in effectiveness of doctoral program. While Cornell was ranked fifteenth among music libraries, it ranked tenth in quality of grad-

TABLE 2

Ranking of Professional Music Schools and Graduate Music Programs*

\begin{tabular}{|c|c|c|}
\hline $\begin{array}{c}\text { Blau-Margulies, } \\
\text { Reputations of Professional } \\
\text { Schools (1974) }\end{array}$ & $\begin{array}{l}\text { Roose-Anderson, } \\
\text { Quality of Graduate Faculty } \\
(1970)\end{array}$ & $\begin{array}{l}\text { Roose-Anderson, } \\
\text { Effectiveness of Doctoral } \\
\text { Programs (1970) }\end{array}$ \\
\hline $\begin{array}{l}\text { 1. Indiana } \\
\text { 2. Eastman } \\
\text { 3. Michigan } \\
\text { 4. Juilliard } \\
\text { 5. Illinois } \\
\text { 6. Curtis } \\
\text { 7. USC } \\
\text { 8. Oberlin }\end{array}$ & $\begin{array}{l}\text { 1. Harvard } \\
\text { 2. Berkeley } \\
\text { 2. Princeton } \\
\text { 4. Yale } \\
\text { 5. Chicago } \\
\text { 6. Illinois } \\
\text { 6. Michigan } \\
\text { 6. NYU } \\
\text { 9. Columbia } \\
\text { 10. UCLA } \\
\text { 10. Cornell } \\
\text { 10. Stanford } \\
\text { 13. Indiana } \\
\text { 14. North Carolina } \\
\text { 14. Eastman } \\
\text { 16. Brandeis } \\
\text { 17. USC }\end{array}$ & $\begin{array}{l}\text { 1. Harvard } \\
\text { 2. Princeton } \\
\text { 3. Berkeley } \\
\text { 3. Yale } \\
\text { 5. Illinois } \\
\text { 5. Michigan } \\
\text { 5. NYU } \\
\text { 8. UCLA } \\
\text { 8. Chicago } \\
\text { 8. Cornell } \\
\text { 8. Stanford } \\
\text { 12. North Carolina } \\
\text { 12. Eastman } \\
\text { 14. Columbia }\end{array}$ \\
\hline
\end{tabular}

\footnotetext{
See appendix for full names of institutions listed.

"Peter M. Blau and Rebecca Z. Margulies, "The Reputations of American Professional Schools," Change 6:42-47 (Dec.-Jan. 1974-75). * Kenneth D. Roose and Charles J. Anderson, A Rating of Graduate Programs (Washington, D.C.: American Council on Education, 1970), p.48-49. Seventeen departments were not ranked in the Roose-Anderson study but grouped alphabetically after the ranked de-
} partments. 
uate faculty and eighth in effectiveness of doctoral program.

The other seven institutions in column one of table 1 show a difference of three ranked positions or less in comparison with the Roose-Anderson ratings. One final comparison should be noted between the fifteen music libraries ranked in column one of table 1 and the Roose-Anderson ratings. New York University, which appears sixth with Illinois and Michigan in quality of graduate faculty and fifth with Illinois and Michigan in effectiveness of doctoral program, was mentioned only twice by the 156 respondents who answered the question concerning the top five music libraries.

\section{Discussion}

Although there appears to be a fairly high overall relationship among studies of music schools and libraries, criticism of rankings and ratings of academic programs and disciplines has been expressed in connection with the Blau-Margulies study, the RooseAnderson ratings, and this study ranking music libraries. Those who oppose the ranking of any departments, schools, or institutions contend that ranking hurts many good schools that didn't quite make the list, establishes a pecking order, and fails to reflect recent deterioration of schools that were once considered quite good. They feel that judgment of deans, peers, and scholars in a field is based on hearsay, lacks firsthand knowledge, and neglects objective measures of quality and achievement.

It is difficult to learn objectively what went through people's minds when they replied to a subjective question such as, "What, in your opinion, are the top five ...?" In some cases, the prestige of the total institution may affect the answer, while in others the reputations of faculty and librarians, who are known to the respondent, may influence the answer to the question. There is general agreement, however, that ratings of faculty, doctoral programs, and libraries constitute only three of several indicators of quality in an academic program and that these indicators should be correlated with more detailed program facets, such as those mentioned at the beginning of this article.

Further analyses and interpretations of this survey of music libraries may be forthcoming, but I would like to point out three conclusions which should not be drawn from the survey.

First, the music libraries at the fifteen institutions listed in column one of table 1 should not be considered the only noteworthy music libraries. Music libraries at other institutions may reveal, upon detailed examination of such factors as materials and services, that they have resources and subject strengths superior to any of the fifteenranked libraries.

Second, the survey does not take into consideration the rich music research resources that may fall outside the jurisdiction of a given academic institution but remain easily accessible to the members of that institution by being located within the same geographical area. Students and faculty at Columbia and New York University, for example, have access to the extensive music research collections at the New York Public Library at Lincoln Center.

Third, until a more detailed study is made, it should not be concluded that a strong relation necessarily exists between fields of study offered by a department or school and the strengths of the music library resources. Strong library collections might be expected in the primary fields of study offered by a given institution, but factors other than opinions would have to be considered in establishing such a connection. In the fields of music theory and/or composition, for example, I suspect that the music library resources available to support the teaching programs would vary a great deal from one institution to another.

In summary, the assessment of music libraries at graduate institutions discloses that, in the judgment of the academic music librarians and AMS members, the quality of fifteen music libraries is high enough to merit a national reputation. In addition, a strong relation exists between the reputations of music departments and schools (especially as related to the quality of the graduate faculty and the effectiveness of the doctoral program) and the reputations of academic music libraries supporting graduate programs. This study constitutes the necessary initial step in a more detailed examination of the characteristics of academic music libraries in the United States. 


\section{APPENDIX \\ INSTITUTIONS INCLUDED IN THE TABLES}

\section{ABBREVIATED}

NAME

Berkeley

Brandeis

Chicago

Columbia

Cornell

Curtis

Eastman

Harvard

Illinois

Indiana

Iowa (Iowa City)

Juilliard

\section{FUll NAME AND STATE}

University of California,
Berkeley

Brandeis University (Massachusetts)

University of Chicago (Illinois)

Columbia University (New York)

Cornell University (New York)

Curtis Institute of Music (Pennsylvania)

University of Rochester, Eastman School of Music (New York)

Harvard University (Massachusetts)

University of Illinois at Urbana-Champaign

Indiana University

University of Iowa

Juilliard School (New York)
Michigan

NYU

North Carolina

North Texas

Northwestern

Oberlin

Pennsylvania

Princeton

Stanford

UCLA

USC

Washington (St. Louis) Washington University

Yale (Missouri)

University of Michigan

New York University

University of North Carolina at Chapel Hill

North Texas State University

Northwestern University (Illinois)

Oberlin College (Ohio)

University of Pennsylvania

Princeton University (New Jersey)

Stanford University (California)

University of California, Los Angeles

University of Southern California

Yale University (Connecticut)

\section{REFERENCES}

1. Malcolm G. Scully, "How to Evaluate Graduate Programs," Chronicle of Higher Education 13:11 (Dec. 6, 1976).

2. List of Members and Subscribers, 1974-1975 (Denton, Tex.: American Musicological Society, 1975); Don Phillips, ed., Directory of Music Librarians in the United States and Canada, a preliminary ed. (Ann Arbor, Mich.: Music Library Association, 1976).
3. Peter M. Blau and Rebecca Z. Margulies, "The Reputations of American Professional Schools," Change 6:42-47 (Dec.-Jan. 197475).

4. Kenneth D. Roose and Charles J. Anderson, A Rating of Graduate Programs (Washington, D.C.: American Council on Education, 1970), p. 48-49.

5. Ibid., p.49. 